\title{
New Amphiphilic Bowl-Shaped Receptors on the Basis of Calix[4]arenes in Cone Conformation: Synthesis, Self-Aggregation and Eosin $Y$ Dye Binding
}

\author{
Vladimir A. Burilov, ${ }^{a} @$ Guzalia A. Fatikhova, ${ }^{a}$ Diana A. Mironova, ${ }^{a}$ \\ Svetlana E. Solovieva, ${ }^{a, b}$ and Igor S. Antipin ${ }^{a, b}$ \\ ${ }^{\mathrm{a}}$ Kazan Federal University, 420008 Kazan, Russian Federation \\ ${ }^{\mathrm{b}}$ A.E. Arbuzov Institute of Organic and Physical Chemistry, 420088 Kazan, Russian Federation \\ ${ }^{\circledR}$ Corresponding authorE-mail:ultrav@bk.ru
}

\begin{abstract}
The first calix[4]arene derivative in cone conformation containing two azidoacetamide groups on the upper rim and two alkyl substituents on the lower rim of the macrocycle was synthesized. It has been shown that this compound is a convenient precursor for the synthesis of broad series of amphiphilic receptors on the calixarene platform in cone stereoisomeric forms using the copper-catalyzed 1,3-dipolar cycloaddition (CuAAC) to terminal alkynes. The formation of 1,2,3-triazoles have been established by one-and two-dimensional NMR spectroscopy. Water soluble bis-ammonium derivative possesses the receptor and surfactant properties. The formation of 2:1 complex (eosin:calixarene) with a negatively charged fluorescent Eosin Y dye was accompanied by a significant quenching of dye fluorescence. This "dark" complex is perspective for the design of the fluorescent sensors for anionic organic substrates, based on the competitive displacement of the dye molecules in the calixarene cavity. Above the critical aggregation concentration $\left(3.3 \cdot 10^{-4} \mathrm{M}\right)$ two types of nanoaggregates with diameter of 27 and $139 \mathrm{~nm}$ are observed, where in the complex stoichiometry remains unchanged.
\end{abstract}

Keywords: Calixarenes, flow hydrogenation, click chemistry, organic azides, 1,2,3-triazoles, eosin $Y$, host-guest complexes.

\section{Новые амфифильные чашеобразные рецепторы на основе каликс[4]аренов в конформации конус: синтез, самоагрегация и связывание красителя эозина $Y$}

\author{
В. А. Бурилов, ${ }^{a}{ }^{@}$ Г. А. Фатыхова, ${ }^{a}$ А. А. Миронова, ${ }^{a}$ С. Е. Соловьева, ${ }^{\text {a, }}$ \\ И. С. Антипин ${ }^{a, b}$ \\ ${ }^{\mathrm{a}}$ Казанский федеральный университет, 420008 Казань, Россия \\ ${ }^{\mathrm{b}}$ Институт органической и физической химии им. А.Е. Арбузова КазНЦ РАН, 420088 Казань, Россия \\ @E-mail: ultrav@bk.ru
}

\begin{abstract}
Впервые получено производное каликс[4]арена в стереоизмерной форме конус, содержащее две азидоацетамидные группь на верхнем ободе и два алкильных заместителя на нижнем ободе макрочикла. Показано, что данное соединение является удобным прекурсором для синтеза широкой серии амфифильных рецепторов на платформе каликсарена в стереоизомернй форме конус с использованием медь-катализируемой реакции 1,3-диполярного ичиклоприсоединения (СиААС) к терминальными алкинам. Образование 1,2,3-триазолов было установлено с использованием одно- и двумерной ЯМР спектроскопии. Водорастворимое бисаммонийное производное обладает рецепторными и поверхностно-активными свойствами. Образование комплекса состава 2:1 (эозин:каликсарен) с отрицательно заряженньмм флуоресцентньлм красителем эозином сопровождается значительным гашением флуоресценции красителя. Такой “тёмный” комплекс эозина $Y$
\end{abstract}


с каликсареном перспективен с точки зрения создания флуоресцентных сенсоров на анионных органических субстратах, основанных на конкурентном вытеснении молекуль красителя из полости каликсарена. Выше критической концентрачии агрегации $\left(3.3 \cdot 10^{-4} \mathrm{M}\right)$ в воде образуются два типа наноагрегатов с диаметром 27 и 139 нм, при этом стехиометрия комплексообразования не меняется.

Ключевые слова: Каликсарены, проточное гидрирование, клик-реакции, органические азиды, 1,2,3-триазолы, эозин $Y$, комплексы гость-хозяин.

\section{Introduction}

The creation of the nanoscale objects through the self-assembly of small molecules is an attractive strategy that brings with it the challenge of controlling the size and structure of the assemblies through interactions at the molecular level. Traditionally, synthetic amphiphiles have been designed to contain nonpolar parts that interact unfavorably with water together with polar subunits that interact favorably with water. However, it is more interesting when the aggregates are formed by amphiphilic synthetic receptors. They can provide functional nanoscale surfaces that can bind to specific guests, thus allowing further noncovalent modification. Moreover, such amphiphilic synthetic receptors can be used as a parts of multifunctional phospholipid vesicles, which attract a considerable interest due to their use in molecular recognition, drug delivery, cell mimics, catalysis and many other applications..$^{[1-3]}$

Selective functionalization of both upper and lower rim in the cone conformation with maintaining the cavity for better host-guest interactions makes calixarenes one of the best platforms for the amphiphilic receptors design. The unique structure and a variety of stereoisomeric forms of calix[4]arene derivatives led to their wide applications in supramolecular chemistry. Their ability to form hostguest complexes and to bind both organic molecules and metal ions is successfully used in extraction; recognition of different substrates and as components of molecular devices. $^{[4-6]}$ Furthermore, these macrocycles are indispensable in the design of biomimetic systems - artificial systems modeling at the molecular level or mimic the reaction and the processes occurring in living organisms. ${ }^{[7]}$

The synthetic potential of calixarene platform can be essentially extended by click-chemistry. ${ }^{[8-10]}$ The wellknown click-reaction, the copper-catalyzed azide-alkyne cycloaddition (CuAAC) was selected to create a uniform synthetic protocol that would allow to vary the receptor units in amphiphilic molecule.

We now report a new synthetic strategy for the synthesis of wide series of amphiphilic receptors through CuAAC reaction of calix[4] arene containing hydrophobic alkyl moieties on the lower rim and azide groups on the upper rim in cone configuration with several alkynes and study of self-aggregation of the synthesized bis-ammonium salt in aqueous media.

\section{Experimental}

All reagents were purchased from either Acros or SigmaAldrich and used without further purification. Solvents were purified according to standard methods. ${ }^{[11]}$ p-tert-Butylcalix[4]arene, 5, 17-ditert-butyl-11,23-dinitro-25,27-dibutyloxy-26,28-dihydroxycalix[4] arene (2) and $N$-propargyl- $N, N, N$-triethylammonium bromide were synthesized according to literature methods. ${ }^{[12-14]}$ Microwave assisted reactions were carried out in the CEM Mars 5 Microwave Accelerated Reaction System. Hydrogenation reaction was carried out on flow hydrogenation reactor H-Cube Pro (Thales Nano Inc.) using $10 \% \mathrm{Pd} / \mathrm{C}$ catalyst (CatCart ${ }^{\circledR}$ THS01131). Cellu Sep H1 dialysis membranes with molecular-weight cutoff (MWCO) limited near $1000 \mathrm{Da}$ are used. Reactions were monitored by TLC using Silufol UV 254 plates.

NMR spectra were recorded on Bruker Avance 400 Nanobay with $\mathrm{CDCl}_{3}\left(\delta_{\mathrm{H}}=7.26 \mathrm{ppm}\right)$ as internal standard. MALDI massspectra were measured on UltraFlex III TOF/TOF with PNA matrix, laser Nd:YAG, $\lambda=355 \mathrm{~nm}$. Elemental analysis of synthesized compounds was done on the Perkin Elmer PE 2400 PHNS/O Elemental Analyzer.

UV-Vis absorbance spectra were recorded on Perkin Elmer Lambda 35 UV/VIS spectrophotometer. The complex stoichiometry was determined by the Job's method in TRIS buffer ( $\mathrm{p} H=7.4$ ) with the total components concentration $0.07 \mathrm{mM}$.

Dynamic light scattering (DLS) measurements were carried out on Zetasizer Nano Z (Malvern Instruments, USA) with $10 \mathrm{~mW}$ $633 \mathrm{~nm} \mathrm{He}-\mathrm{Ne}$ laser light source and the light scattering angle of 173. The data were treated with DTS software (Dispersion Technology Software 5.00). The solutions were filtered through Millex HV $0.45 \mu \mathrm{M}$ filter before the measurements to remove dust. The experiments were carried out in the disposable plastic cells DTS 0012 (Sigma-Aldrich, USA) at $25^{\circ} \mathrm{C}$ with at least three experiments for each system. Statistical data treatment was done using t-Student coefficient, and the particle size determination error was less $2 \%$.

Fluorescence titrations were performed in $1 \mathrm{~cm}$ quartz cuvettes and recorded on a Fluorolog FL-221 spectrofluorimeter (HORIBA Jobin Yvon) in the range of 350 to $430 \mathrm{~nm}$ and excitation wavelength $335 \mathrm{~nm}$ with $2.5 \mathrm{~nm}$ slit. All studies were conducted in buffered aqueous solution (TRIS buffer, $\mathrm{pH}=7.4$ ) at $298 \mathrm{~K}$.

\section{Synthesis}

5,17,11,23-Tetra-tert-butyl-25,27-dibutyloxy-26,28-dihydroxycalix[4]arene (1). Mixture of p-tert-butylcalix[4]arene (5.0 g, $7.7 \mathrm{mmol})$, potassium carbonate $(2.13 \mathrm{~g}, 15 \mathrm{mmol}), 1$-bromobutane $(2.06 \mathrm{ml}, 19 \mathrm{mmol})$, potassium iodide $(7.5 \mathrm{~g}, 45 \mathrm{mmol})$, tetrabutylammonium bromide TBAB $(0.25 \mathrm{~g}, 0.77 \mathrm{mmol})$ and acetone $(40 \mathrm{ml})$ was placed in the teflon reactor (Easy Prep $\mathrm{CEM}^{\circledR}$ corp.) and heated at $130{ }^{\circ} \mathrm{C}$ with the magnetic stirring in a microwave oven during 2 hours (irradiation power $400 \mathrm{~W}$ ). Then the reaction mixture was neutralized with $1 \mathrm{M}$ hydrochloric acid and diluted with $50 \mathrm{ml}$ of $\mathrm{CHCl}_{3}$. The organic phase was washed with water, dried over $\mathrm{MgSO}_{4}$ and then solvent was removed to give slightly yellow oil. The product (3.91 g, $78 \%$ ) was isolated after precipitation by ethanol, filtration and drying in vacuo as white solid. ${ }^{1} \mathrm{H}$ NMR spectra is in agreement with literature. ${ }^{[15]}$

5,17-Di-tert-butyl-11,23-diamino-25,27-dibutyloxy-26,28dihydroxycalix[4]arene (3). THF solution of compound 2 
$(0.05 \mathrm{M})$ was pumped through the flow hydrogenation reactor at a temperature of $120^{\circ} \mathrm{C}$ and a hydrogen pressure 30 bar at $1 \mathrm{ml} / \mathrm{min}$ flow rate. Solvent evaporation in vacuo gave $0.35 \mathrm{~g}(91 \%)$ a pale pink solid. ${ }^{1} \mathrm{H}$ NMR and ${ }^{13} \mathrm{C}$ spectra are in agreement with literature data. ${ }^{[16]}$

5,17-Di-tert-butyl-11,23-bis(2-bromoacetamide)-25,27dibutyloxy-26,28-dihydroxycalix[4]arene (4). $\alpha$-Bromoacetyl bromide $(0.31 \mathrm{ml}, 3.52 \mathrm{mmol})$ dissolved in $20 \mathrm{ml} \mathrm{CH}_{2} \mathrm{Cl}_{2}$ was added dropwise to the solution of compound $3(1.09 \mathrm{~g}, 1.60 \mathrm{mmol})$ and triethylamine $(0.45 \mathrm{ml}, 3.21 \mathrm{mmol})$ in $20 \mathrm{ml}$ of $\mathrm{CH}_{2} \mathrm{Cl}_{2}$ over 1 hour under inert atmosphere. The mixture was stirred 4 hours and then diluted with $40 \mathrm{ml}$ of water. The organic phase was washed with saturated $\mathrm{NaCl}$, dried over $\mathrm{MgSO}_{4}$, and $1.2 \mathrm{~g} \mathrm{(82 \% )} \mathrm{of} \mathrm{the} \mathrm{crude}$ white solid was isolated after the solvent evaporation in vacuo. Found, \%: C, 61.78; H, 5.93; N, 2.99. $\mathrm{C}_{48} \mathrm{H}_{60} \mathrm{Br}_{2} \mathrm{~N}_{2} \mathrm{O}_{6}$. Calculated, \%: C, 62.61; H, 6.57; N, 3.04. Mass spectrum (MALDI TOF) $\mathrm{m} / \mathrm{z}$ : $920.05[\mathrm{M}]^{+} .{ }^{1} \mathrm{H}$ NMR $\left(400 \mathrm{MHz}, \mathrm{CDCl}_{3}, 25^{\circ} \mathrm{C}\right) \delta_{\mathrm{H}} \mathrm{ppm}: 1.07(\mathrm{t}$, $\left.{ }^{3} J=7.4 \mathrm{~Hz}, 6 \mathrm{H}, \mathrm{CH}_{3}\right), 1.10\left(\mathrm{~s}, 18 \mathrm{H}, \mathrm{C}\left(\mathrm{CH}_{3}\right)_{3}\right), 1.64-1.76(\mathrm{~m}, 4 \mathrm{H}$, $\left.\mathrm{CH}_{2}\right), 2.01-2.09\left(\mathrm{~m}, 4 \mathrm{H}, \mathrm{CH}_{2}\right), 3.33\left(\mathrm{~d},{ }^{2} \mathrm{~J}=13.0 \mathrm{~Hz}, 4 \mathrm{H}, \mathrm{ArCH} \mathrm{Ar}_{2}\right.$, 3.94-4.03 (m, 8H, $\left.\mathrm{OCH}_{2},-\mathrm{C}(\mathrm{O}) \mathrm{CH}_{2} \mathrm{Br}\right), 4.28\left(\mathrm{~d},{ }^{2} \mathrm{~J}=12.9 \mathrm{~Hz}, 4 \mathrm{H}\right.$, $\left.\mathrm{ArCH}_{2} \mathrm{Ar}\right), 6.94$ (s, 4H, ArH), 7.19 (s, 4H, ArH), 7.87 (s, 2H, NH), $8.32(\mathrm{~s}, 2 \mathrm{H}, \mathrm{ArOH}) .{ }^{13} \mathrm{C} \mathrm{NMR}\left(101 \mathrm{MHz}, \mathrm{CDCl}_{3}, 25{ }^{\circ} \mathrm{C}\right) \delta_{\mathrm{C}} \mathrm{ppm}$ : $14.23,19.48,29.86,31.44,31.86,32.30,34.34,120.75,125.96$, 128.46, 129.33, 132.78, 147.67, 150.34, 150.75, 162.86 .

5,17-Di-tert-butyl-11,23-bis(2-azidoacetamide)-25,27dibutyloxy-26,28-dihydroxycalix [4]arene (5). Mixture of compound $4(1.2 \mathrm{~g}, 1.30 \mathrm{mmol})$ and sodium azide $(0.85 \mathrm{~g}, 13 \mathrm{mmol})$ in $10 \mathrm{ml}$ of dry DMF was stirred 1 hour at $40{ }^{\circ} \mathrm{C}$. Then reaction mixture was concentrated and diluted with $\mathrm{CHCl}_{3}$. The organic phase was washed with $3 \times 50 \mathrm{ml}$ of water, dried over $\mathrm{Na}_{2} \mathrm{SO}_{4}$. The crude product $(0.64 \mathrm{~g}, 64 \%)$ was isolated as white solid after solvent evaporation in vacuo. Found, \%: C, 67. 87; H, 6.93; N, 13.19. $\mathrm{C}_{48} \mathrm{H}_{60} \mathrm{~N}_{8} \mathrm{O}_{6}$. Calculated, \%: C, 68.22; H, 7.16; N, 13.26. Mass spectrum (MALDI TOF) $m / z: 845.70[\mathrm{M}+\mathrm{H}]^{+} .{ }^{1} \mathrm{H}$ NMR $(400 \mathrm{MHz}$, $\left.\mathrm{CDCl}_{3}, 25^{\circ} \mathrm{C}\right) \delta_{\mathrm{H}} \mathrm{ppm}: 1.07\left(\mathrm{t},{ }^{3} \mathrm{~J}=7.4 \mathrm{~Hz}, 6 \mathrm{H}, \mathrm{CH}_{3}\right), 1.09(\mathrm{~s}, 18 \mathrm{H}$, $\left.\left(\mathrm{CH}_{3}\right)_{3}\right), 1.65-1.76\left(\mathrm{~m}, 4 \mathrm{H}, \mathrm{CH}_{2}\right), 2.00-2.09\left(\mathrm{~m}, 4 \mathrm{H}, \mathrm{CH}_{2}\right), 3.33(\mathrm{~d}$, $\left.{ }^{2} \mathrm{~J}=13.0 \mathrm{~Hz}, 4 \mathrm{H}, \mathrm{ArCH}_{2} \mathrm{Ar}\right), 3.98\left(\mathrm{t},{ }^{3} \mathrm{~J}=6.7 \mathrm{~Hz}, 4 \mathrm{H},-\mathrm{OCH}_{2}\right), 4.05$ (s, $\left.4 \mathrm{H},-\mathrm{C}(\mathrm{O}) \mathrm{CH}_{2} \mathrm{~N}_{3}\right), 4.30\left(\mathrm{~d},{ }^{2} \mathrm{~J}=12.9 \mathrm{~Hz}, 4 \mathrm{H}, \mathrm{ArCH}_{2} \mathrm{Ar}\right), 6.95$ (s, $4 \mathrm{H}, \mathrm{ArH}), 7.21$ (s, 4H, ArH), 7.78 (s, 2H, NH), 8.32 (s, 2H, ArOH). ${ }^{13} \mathrm{C}$ NMR $\left(101 \mathrm{MHz}, \mathrm{CDCl}_{3}, 25{ }^{\circ} \mathrm{C}\right) \delta_{\mathrm{C}} \mathrm{ppm}: 14.21,19.47,31.43$, $31.60,31.86,32.29,34.31,36.54,50.21,53.08,120.89,125.94$, $128.26,129.22,132.73,147.65,150.31,162.91,164.21$.

General method for synthesis of 6 and 7 . Compound $5(0.1 \mathrm{~g}$, $0.118 \mathrm{mmol})$, copper(I) iodide $(6.8 \mathrm{mg}, 0.036 \mathrm{mmol}), 0.36 \mathrm{mmol}$ of corresponding alkyne and triethylamine $(2 \mathrm{ml}, 7.2 \mathrm{mmol})$ were dissolved in $5 \mathrm{ml}$ of dry toluene. The mixture was stirred for 2 hours at $40{ }^{\circ} \mathrm{C}$ under argon and then passed through a pad of silica using ethyl acetate (for 6) or ethyl acetate/methanol 1:1 (for 7) as eluent. Crude white solids were isolated $(0.10 \mathrm{~g}, 83 \%$ of 6 ; $0.09 \mathrm{~g}, 81 \%$ of 7) after the solvent evaporation and drying residues in vacuo.

5,17-Di-tert-butyl-11,23-bis(2-(4-(phenyl)-1H-1,2,3-triazol1-yl)acetamide)-25,27-dibutyloxy-26,28-dihydroxy-calix [4]arene (6). Found, \%: C, 73.12; H, 6.90; N, 10.50. $\mathrm{C}_{64} \mathrm{H}_{72} \mathrm{~N}_{8} \mathrm{O}_{6}$. Calculated, $\%$ : C, 73.26; H, 6.92; N, 10.68. Mass spectrum (MALDI TOF) $\mathrm{m} / \mathrm{z}$ : $1049.32[\mathrm{M}+\mathrm{H}]^{+} .{ }^{1} \mathrm{H}$ NMR $\left(400 \mathrm{MHz}, \mathrm{CDCl}_{3}, 25{ }^{\circ} \mathrm{C}\right) \delta_{\mathrm{H}} \mathrm{ppm}$ : $1.01\left(\mathrm{~s}, 18 \mathrm{H}, \mathrm{C}\left(\mathrm{CH}_{3}\right)_{3}\right), 1,06\left(\mathrm{t},{ }^{3} J=7.3 \mathrm{~Hz}, 6 \mathrm{H}, \mathrm{CH}_{3}\right), 1.65-1.73$ $\left(\mathrm{m}, 4 \mathrm{H}, \mathrm{CH}_{2}\right), 1.98-2.07\left(\mathrm{~m}, 4 \mathrm{H}, \mathrm{CH}_{2}\right), 3.28\left(\mathrm{~d},{ }^{2} \mathrm{~J}=12.9 \mathrm{~Hz}, 4 \mathrm{H}\right.$, $\left.\mathrm{ArCH}_{2} \mathrm{Ar}\right), 3.95$ (t, $\left.{ }^{3} \mathrm{~J}=6.6 \mathrm{~Hz}, 4 \mathrm{H},-\mathrm{OCH}_{2}\right), 4.25\left(\mathrm{~d},{ }^{2} J=12.9 \mathrm{~Hz}\right.$, $\left.4 \mathrm{H}, \mathrm{ArCH}_{2} \mathrm{Ar}\right), 5.21$ (s, 4H, $\left.-\mathrm{C}(\mathrm{O}) \mathrm{CH}_{2}\right), 6.88$ (s, 4H, $\left.\mathrm{ArH}\right), 7.18$ (s, 4H, ArH), 7.27-7.34 (s, 2H, ArH), 7.36-7.42 (s, 4H, ArH), 7.82 (d, $\left.{ }^{3} J=7.2 \mathrm{~Hz}, 4 \mathrm{H}, \mathrm{ArH}\right), 7.96$ (s, 2H, NH), 8.00 (s, 2H, CH), 8.31 (s, $2 \mathrm{H}, \mathrm{ArOH}) .{ }^{13} \mathrm{C} \mathrm{NMR}\left(101 \mathrm{MHz}, \mathrm{CDCl}_{3}, 25{ }^{\circ} \mathrm{C}\right) \delta_{\mathrm{C}} \mathrm{ppm}: 14.20$, $19.45,31.34,31.79,32.26,34.22,53.99,120.86,121.48,125.94$, $128.29,128.68,129.04,129.23,130.01,132.61,147.62,148.64$, $150.21,150.74,162.57$

5,17-Di-tert-butyl-11,23-bis(2-(4-(hydroxymethyl)-1H-1,2,3triazol-1-yl)acetamide)-25,27-dibutyloxy-26,28-dihydroxy-calix [4] arene (7). Found, \%: C, 67.60; $\mathrm{H}, 7.02 ; \mathrm{N}, 11.64 . \mathrm{C}_{54} \mathrm{H}_{68} \mathrm{~N}_{8} \mathrm{O}_{8}$.
Calculated, \%: C, 67.76; H, 7.16; N, 11.71. Mass spectrum (MALDI TOF) $m / z: 956.42[\mathrm{M}]^{+} .{ }^{1} \mathrm{H}$ NMR $\left(400 \mathrm{MHz}, \mathrm{CDCl}_{3}, 25^{\circ} \mathrm{C}\right) \delta_{\mathrm{H}} \mathrm{ppm}$ : $1.06\left(\mathrm{t},{ }^{3} J=7.4 \mathrm{~Hz}, 6 \mathrm{H}, \mathrm{CH}_{3}\right), 1.08\left(\mathrm{~s}, 18 \mathrm{H},\left(\mathrm{CH}_{3}\right)_{3}\right), 1.64-1.74$ $\left(\mathrm{m}, 4 \mathrm{H}, \mathrm{CH}_{2}\right), 1.97-2.09\left(\mathrm{~m}, 4 \mathrm{H}, \mathrm{CH}_{2}\right), 3.29\left(\mathrm{~d},{ }^{2} J=13.0 \mathrm{~Hz}, 4 \mathrm{H}\right.$, $\left.\mathrm{ArCH}_{2} \mathrm{Ar}\right), 3.96\left(\mathrm{t},{ }^{3} \mathrm{~J}=6.7 \mathrm{~Hz}, 4 \mathrm{H},-\mathrm{OCH}_{2}\right), 4.27$ (d, ${ }^{2} \mathrm{~J}=12.9 \mathrm{~Hz}$, $\left.4 \mathrm{H}, \mathrm{ArCH}_{2} \mathrm{Ar}\right), 4.79$ (s, 4H, - $\left.\mathrm{CH}_{2} \mathrm{OH}\right), 5.13$ (s, 4H, C(O)CH $), 6.92$ (s, 4H, ArH), 7.14 (s, 4H, ArH), $7.71(\mathrm{~s}, 2 \mathrm{H}, \mathrm{NH}), 7.84(\mathrm{~s}, 2 \mathrm{H}, \mathrm{CH})$, 8.34 (s, $2 \mathrm{H}, \mathrm{ArOH}) .{ }^{13} \mathrm{C}$ NMR $\left(101 \mathrm{MHz}, \mathrm{CDCl}_{3}, 25^{\circ} \mathrm{C}\right) \delta_{\mathrm{C}} \mathrm{ppm}:$ 1.16, 10.11, 14.23, 19.49, 29.84, 31.44, 31.86, 32.30, 46.02, 53.19, $120.73,125.95,129.23,132.71$.

5,17-Di-tert-butyl-11,23-bis(2-(4-(N,N,N-triethylammoniummethyl)-1H-1,2,3-triazol-1-yl)acetamide)-25,27-dibutyloxy-26,28-dihydroxy-calix[4]arene dibromide (8). Mixture of azide $5(0.15 \mathrm{~g}, 0,18 \mathrm{mmol}), N$-propargyl- $N, N, N$-triethylammonium bromide $(0.098 \mathrm{~g}, 0.44 \mathrm{mmol})$, triethylamine $(1.25 \mathrm{ml}$, $8.8 \mathrm{mmol}$ ), copper(I) iodide (1.7 $\mathrm{mg}, 0.0089 \mathrm{mmol})$ and $10 \mathrm{ml}$ of toluene-DMF (1:1) mixture was stirred under argon for one hour at $60{ }^{\circ} \mathrm{C}$. After solvent evaporation light brown solid was dissolved in $5 \mathrm{ml}$ of water and putted in dialysis membrane (with MWCO 1000 ), washed with deionized water and then dried in desiccator over $\mathrm{P}_{2} \mathrm{O}_{5}$ to give $0.19 \mathrm{~g}(83 \%)$ of $\mathbf{8}$ as light brown solid. Found, \%: C, 61.09; H, 6.97; N, 10.07. $\mathrm{C}_{66} \mathrm{H}_{96} \mathrm{Br}_{2} \mathrm{~N}_{10} \mathrm{O}_{6}$. Calculated, \%: C, 61.67; H, 7.53; N, 10.90. Mass spectrum (MALDI TOF) $\mathrm{m} / \mathrm{z}$ : $1284.59[\mathrm{M}]^{+} .{ }^{1} \mathrm{H}$ NMR $\left(400 \mathrm{MHz}, \mathrm{DMSO}-d_{6}, 25^{\circ} \mathrm{C}\right) \delta_{\mathrm{H}} \mathrm{ppm}: 1.11$ (s, $\left.18 \mathrm{H}, \mathrm{C}\left(\mathrm{CH}_{3}\right)_{3}\right), 1.31\left(\mathrm{t},{ }^{3} \mathrm{~J}=7.0 \mathrm{~Hz}, 24 \mathrm{H}, \mathrm{C}\left(\mathrm{CH}_{3}\right)_{3}, \mathrm{CH}_{3}\right), 1.67-1.82$ (m, 4H, $\left.\mathrm{CH}_{2}\right), 1.93-2.03\left(\mathrm{~m}, 4 \mathrm{H}, \mathrm{CH}_{2}\right), 3.19\left(\mathrm{~m}, 16 \mathrm{H}, \mathrm{ArCH}_{2} \mathrm{Ar}\right.$, $\left.\mathrm{CH}_{2}(\mathrm{Et})\right), 3.93\left(\mathrm{~s}, 4 \mathrm{H}, \mathrm{OCH}_{2}\right), 4.18\left(\mathrm{~d},{ }^{2} \mathrm{~J}=12.8 \mathrm{~Hz}, 4 \mathrm{H}, \mathrm{ArCH}_{2} \mathrm{Ar}\right)$, $4.61\left(\mathrm{~s}, 4 \mathrm{H}, \mathrm{CH}_{2} \mathrm{~N}\right), 5.36\left(\mathrm{~s}, 4 \mathrm{H}, \mathrm{C}(\mathrm{O}) \mathrm{CH}_{2}\right), 7.04(\mathrm{~s}, 2 \mathrm{H}, \mathrm{ArH}), 7.31$ (s, 2H, ArH), 8.47 (s, 2H, CH), $8.75(\mathrm{~s}, 2 \mathrm{H}, \mathrm{ArOH}), 10.17$ (s, 2H, $\mathrm{NH}) .{ }^{13} \mathrm{C}$ NMR $\left(101 \mathrm{MHz}, \mathrm{DMSO}-d_{6}, 25^{\circ} \mathrm{C}\right) \delta_{\mathrm{C}} \mathrm{ppm:} \mathrm{7.26,} \mathrm{13.77,}$ $18.75,30.90,31.39,31.63,33.83,50.47,52.06,76.03,78.87,119.86$, $125.49,127.82,129.42,132.40,134.32,146.84,149.10,149.70$, 162.73 .

\section{Results and Discussion}

\section{Synthesis of Calixareneazide Derivative and its Click Reactions}

Some examples of calixarene derivatives bearing azidoalkyl fragments on the macrocycle upper rim are described in the literature. ${ }^{[17-19]}$ Nevertheless, azide groups connected to the calixarene platform via acetamide bridges fragments are very promising because acetamide bridges may also take part in binding of organic guests via strong hydrogen bonds or take part in anion binding. ${ }^{[20]}$

Principally, there are two approaches to realize $\mathrm{CuAAC}$ reactions on the calixarene platform: 1,3-dipole-on-the-calix or dipolarophile-on-the-calix. It was shown for the synthesis of galactosyl- and lactosylcalix[4]arenes ${ }^{[2]}$ that both approaches gave practically the same yield on the final step and choice of the synthetic strategy depends on the reagents availability. For our purposes to prepare amphiphiles with different receptor groups the first route was exploited. It was based on the connection of the calix [4] arene decorated at the upper rim with azido groups and terminal alkynes (Figure 1).

Earlier we have reported ${ }^{[22]}$ on effective method for $p$-tert-butylcalix[4]arene alkylation under microwave irradiation leading to high yields of distal disubstituted ethers for the short time. Using this method dibutyl-substituted calixarene 1 was synthesized in $78 \%$ yield for $2 \mathrm{~h}$ (Figure 1). The method was optimized up to several grams scale. Ipso-nitration of $\mathbf{1}$ was done according to published proce- 

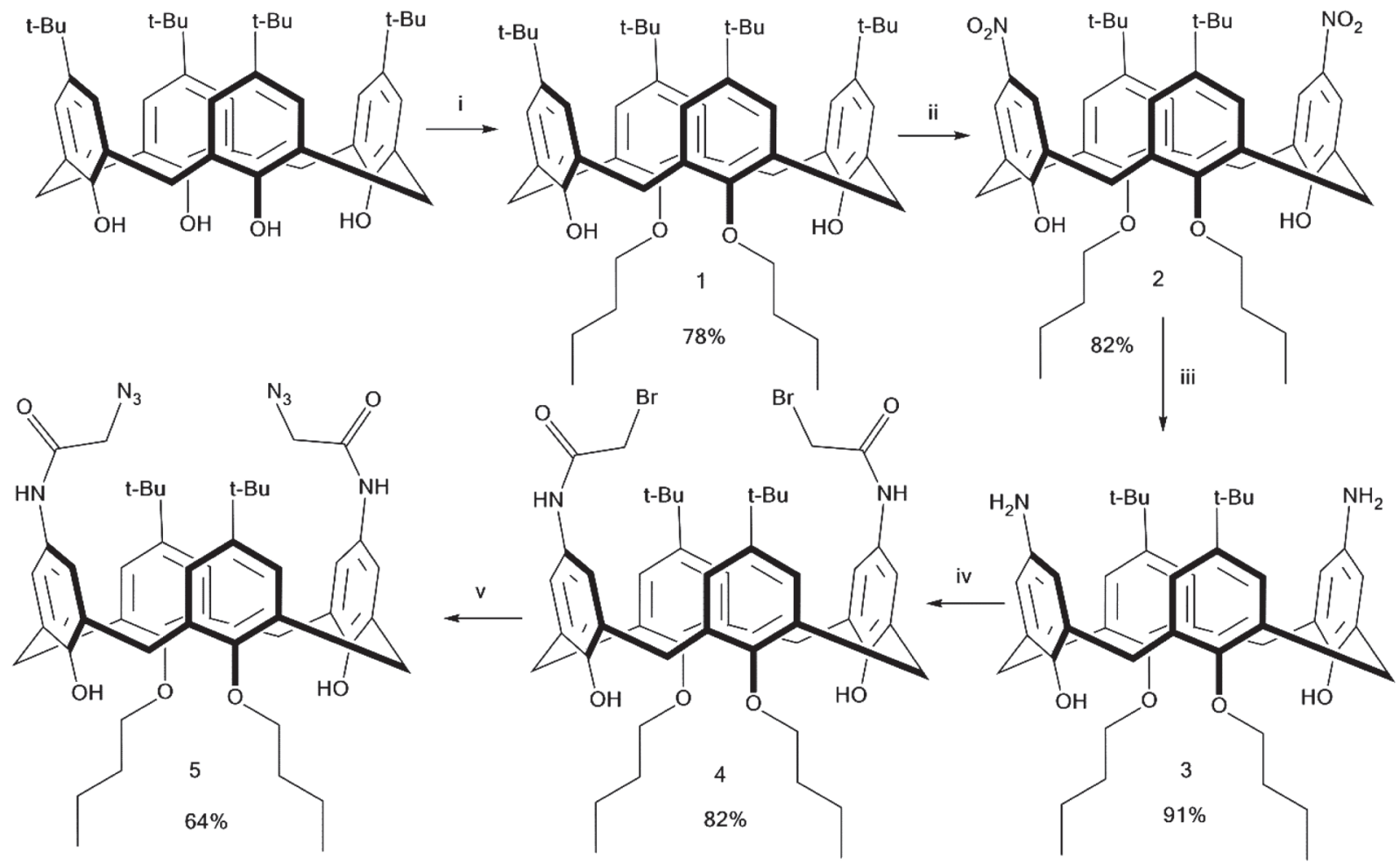

Figure 1. Reaction conditions: $\mathrm{i}-\mathrm{C}_{4} \mathrm{H}_{9} \mathrm{Br}$, TBAB, $\mathrm{K}_{2} \mathrm{CO}_{3}$, $\mathrm{KI}$, acetone, $\mathrm{MW} 400 \mathrm{~W}, 130{ }^{\circ} \mathrm{C}$; ii $-\mathrm{HNO}_{3} / \mathrm{CH}_{3} \mathrm{COOH}, \mathrm{CHCl}, \mathrm{RT}$; iii $-\mathrm{Pd} / \mathrm{C}$ $10 \%$, THF; iv: $\mathrm{BrCH}_{2} \mathrm{COBr}, \mathrm{NEt}_{3}, \mathrm{CH}_{2} \mathrm{Cl}_{2}$; iv $-\mathrm{NaN}_{3}, \mathrm{DMF}$.

dure $^{[23]}$ to give dinitro-derivative 2 in $82 \%$ yield. Diamine $\mathbf{3}$ was synthesized by heterogeneous hydrogenation of $\mathbf{2}$ in flow reactor H-Cube Pro (Thales Nano Inc.) in full hydrogen mode on $10 \% \mathrm{Pd} / \mathrm{C}$. Hydrogenation in flow conditions leads to practically quantitative yield of diamine $\mathbf{3}$ and product was easily isolated by solvent evaporation. Amide 4 was synthesized by the acylation reaction of $\mathbf{3}$ with $\alpha$-bromoacetyl bromide in the presence of base $\left(\mathrm{NEt}_{3}\right)$. The nucleophilic substitution of bromine by azide anion in amide 4 activated by electron withdrawing $\mathrm{C}=\mathrm{O}$ group gave azide $\mathbf{5}$ for $1 \mathrm{~h}$ at room temperature.

Structures of all compounds were established by oneand two-dimensional NMR, elemental analysis and MALDITOF data. In 2D NOESY spectra of 5 there are cross-peaks between signals of hydroxyl protons $(\delta=8.28 \mathrm{ppm})$ and protons of butyl fragments $(\delta=1.70 ; 2.04 ; 3.97$ ppm), crosspeaks between signals of bridging methylene group protons $(\delta=3.32 \mathrm{ppm})$ with aromatic protons $(\delta=7.21 ; 6.94 \mathrm{ppm})$ and cross-peak between signal of amide proton and methylene protons of acetyl fragments, that is fully consistent with the proposed structure in cone stereoisomeric form.

The obtained bis-azide $\mathbf{5}$ was involved in azide-alkyne cycloaddition with phenylacetylene, propargyl alcohol and $N$-propargyl- $N, N, N$-triethylammonium bromide (Figure 2). Synthesis was carried out at $40{ }^{\circ} \mathrm{C}$ and stirred for $1-2$ hours with equivalent amount of corresponding alkyne using $\mathrm{CuI}$ as catalyst in the presence of $\mathrm{NEt}_{3}$ under an inert atmosphere to avoid side Glaser coupling. Efficiency of such catalytic system applied to calixarenes has been shown in our previous works. ${ }^{[10,24]}$ Products $\mathbf{6}$ and $\mathbf{7}$ were isolated by flash chromatography. Ammonium salt 8 turned out to be a water-

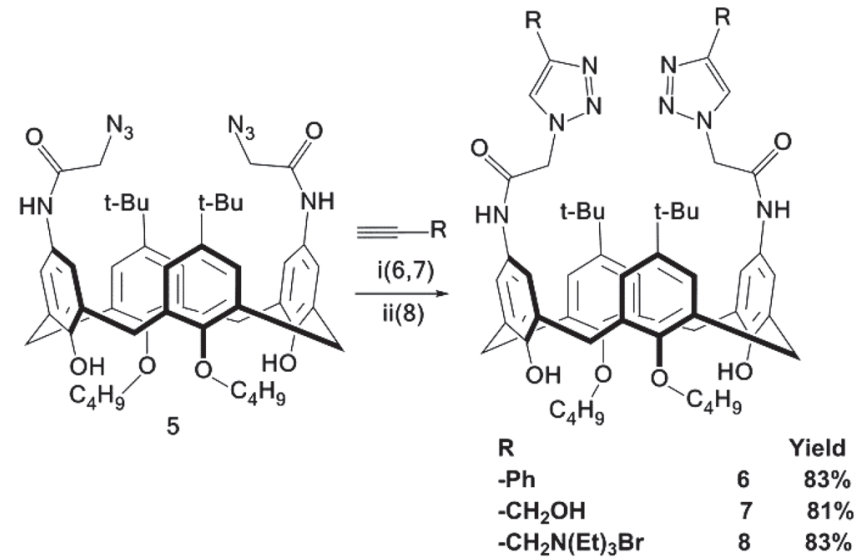

Figure 2. Reaction conditions: $\mathrm{i}$ - alkyne, $\mathrm{CuI}, \mathrm{NEt}_{3}$, toluene; ii - alkyne, CuI, $\mathrm{NEt}_{3}$, toluene-DMF 1:1.

soluble and was purified using dialysis membrane.

Macrocycles 6-8 were fully characterized by ${ }^{1} \mathrm{H}$ and ${ }^{13} \mathrm{C}$ NMR spectroscopy, which displayed the disappearance of the alkyne protons and the appearance of the typical signal of 1,4- disubstituted triazole protons at 7.8-8.5 ppm $\left(\mathrm{CDCl}_{3}\right)$. In the ${ }^{13} \mathrm{C} \mathrm{NMR}$ spectrum $\mathrm{C}_{5}$ atom of triazole ring has signal at $\delta=119-121 \mathrm{ppm}$ that indicates on the formation of 1,4-disubstituted 1,2,3-triazoles according to the literature criteria. ${ }^{[25,26]}$ MALDI-TOF analysis has shown a peak for the $[\mathrm{M}+\mathrm{Na}]^{+}$adducts, which confirms the formation of two 1,2,3-triazole rings. 


\section{Self-Aggregation and Binding of Ammonium} Calixarene 8 with Eosin $Y$

Critical aggregation concentration (CAC) and aggregates size were measured for calixarene $\mathbf{8}$ (herein after CA8) containing two charged ammonium fragments. To determine CAC values the approach based on the concentration dependence of intensity ratio of the first $\mathrm{I}_{1}$ $(373 \mathrm{~nm})$ and third $\mathrm{I}_{3}(384 \mathrm{~nm})$ bands in the emission spectrum of pyrene ${ }^{[27]}$ was used. According to the data obtained, CA8 didn't effect on the typical fine vibrational structure of pyrene spectrum in solution. However, the intensity ratio of the first and third peaks of pyrene (Figure 3 ) changes due to a decrease in the polarity of the environment of the probe caused by the solubilization of pyrene in the hydrophobic core of the CA8 micelles. The value of $\mathrm{CAC}=3.3 \cdot 10^{-4} \mathrm{~mol} / 1$ was determined by kinks in the curve (Figure 3 ).

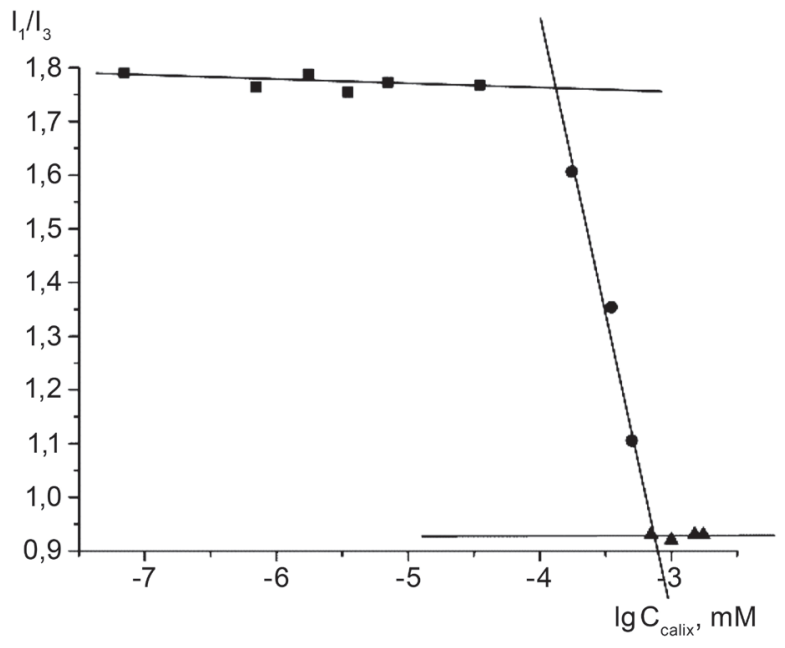

Figure 3. Dependence of $I_{I} / I_{3}$ pyrene ratio $\left(C=1 \cdot 10^{-6} \mathrm{M}\right)$ vs CA8 concentration in $\mathrm{H}_{2} \mathrm{O}$.

DLS analysis of the aqueous CA8 solutions has shown that aggregates with diameter $27 \mathrm{~nm}$ and $139 \mathrm{~nm}$ are present

A

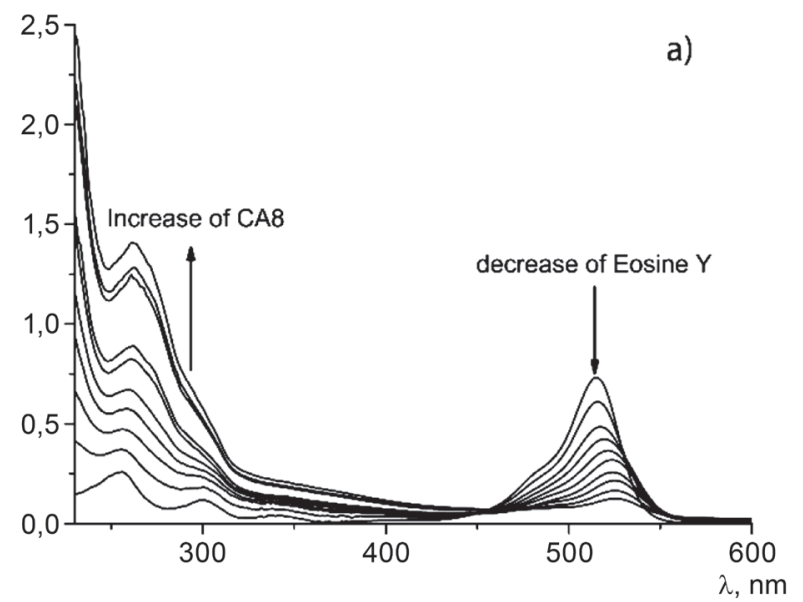

in the solution at concentrations of $0.33 \mathrm{mM}$ (CAC) and $1 \mathrm{mM}$ (above the CAC). It can be assumed that the $27 \mathrm{~nm}$ particles correspond to the large micelles and $139 \mathrm{~nm}$ diameter particles may be vesicles or aggregates of the micelles.

We have found that the addition of CA 8 to aqueous solution of eosin $Y$ dye at $\mathrm{pH}=7.4$ leads to a small bathochromic shift ( $8 \mathrm{~nm}$ ) of the absorption band maximum of the dye, but causes a strong emission quenching of the dye (the intensity decreases by more than 12 times) (Figure 4). Therefore, the observed changes in absorption and emission spectra of eosin $Y$ indicate on the host-guest interactions due to strong electrostatic interactions between positively charged calixarene and negatively charged dye.

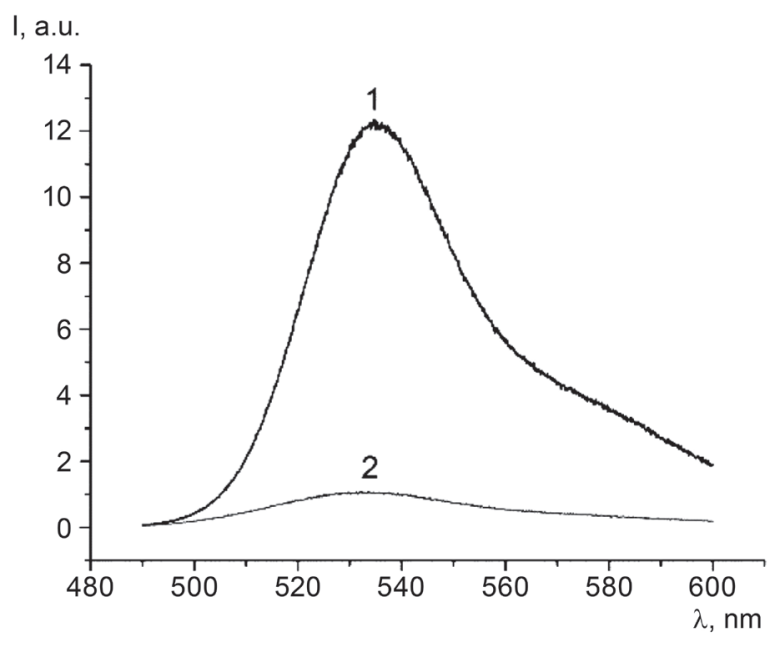

Figure 4. Emission spectra of eosin $Y(0.07 \mathrm{mM})(1)$ and eosin $Y$-CA8 1:1 $(0.07 \mathrm{mM})(2)$ in TRIS buffer $(10 \mathrm{mM}), \mathrm{p} H=7.4$.

The stoichiometry of eosin Y-CA8 complex was determined by isomolar series method (Job method) in TRIS buffer at $\mathrm{pH}=7.4$ for solutions with total concentration of CA8 and eosin Y $0.07 \mathrm{mmol} / 1$. According to the obtained

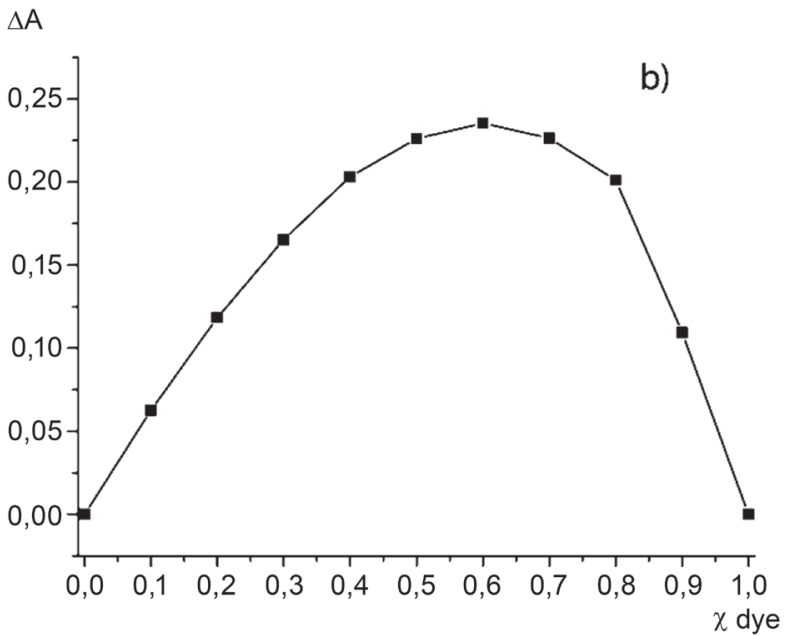

Figure 5. Absorption of isomolar series of eosin $Y$-CA8 mixtures with total concentration of $0.07 \mathrm{mmol} / \mathrm{l}$ in TRIS buffer (10 mM), $\mathrm{p} H=7.4$. (a); corresponding Job's plot for eosin $Y$-CA8 mixture (b). 
Job's curves (Figure 5,b) stoichiometry of eosin $Y$-CA8 complexes is defined as $2: 1$.

Thus, significant change in the photophysical characteristics of the eosin $Y$ upon binding with CA8 can be used in future for creation of a fluorescence sensor which operates based on the competitive displacement of dye from the cavity of the macrocycle with a consequent increase of fluorescence.

\section{Conclusions}

New calix[4]arene derivative bearing azidoacetamide fragments on the upper rim in cone stereoisomeric form was synthesized. The obtained azidoacetamide calixarene derivative was used in click-reactions with several terminal alkynes. Structure of all triazoles was characterized by oneand two-dimensional NMR experiments. The developed approach based on click reactions of azidoacetamidecalix[4] arene derivative with acetylenes of different types is universal and can be successfully used at synthesis of wide series of amphiphilic receptors on calixarene platform in cone stereoisomeric form. Calixarene $\mathbf{8}$ bearing two ammonium fragments was found to form "dark" complexes with eosin $Y$ with quenched fluorescence which is very promising for the creation of different fluorescent sensors.

Acknowledgements. We thank the Russian Scientific Foundation for the financial support of this work (grant № 14-13-01151).

\section{References}

1. Ariga K., Ito H., Hill J.P., Tsukube H. Chem. Soc. Rev. 2012, $41,5800-5835$.

2. Voskuhl J., Ravoo B.J. Chem. Soc. Rev. 2009, 38, 495-505.

3. Gruber B., Balk S., König B. Angew. Commun. 2012, 51, 10060-10063.

4. Giuliani M., Morbioli I., Sansone F., Casnati A. Chem. Commun. 2015, 51, 14140-14159.

5. Morohashi N., Narumi F., Iki N., Hattori T., Miyano S. Chem. Rev. 2006, 106, 5291-5316.
6. Vicens J., Harrofield J. Calixarenes in Nanoworld. Netherlands: Springer, 2007. 392 p.

7. Mirgorodskaya A.B., Yackevich E.I., Kudryashova Yu.R., Kashapov R.R., Solovieva S.E., Gubaidullin A.T., Antipin I.S., Zakharova L.Ya., Konovalov A.I.. Colloids Surf. B 2014, 117, 497-504.

8. Rostovtsev V.V., Green L.G., Fokin V.V., Sharpless K.B. Angew. Chem. Int. Ed. 2002, 41, 2596-2599.

9. Sokolova N., Nenajdenko V.G. RSC $A d v$. 2013, 3, 1621216242.

10. Burilov V.A., Nugmanov R.I., Popova E.V., Nabiullin I.R., Solovieva S.E., Antipin I.S., Konovalov A.I. Macroheterocycles 2014, 7, 10-17.

11. Armarego W.L.F., Chai C.L.L. Purification of Laboratory Chemicals. New York: Elsevier, 2009. 760 p.

12. Gutsche D., Balram D., Kwang H.N., Muthukrishnan R. J. Am. Chem. Soc. 1981, 103, 3782-3792.

13. Verboom W., Durie A., Egberink R.J.M., Asfari Z., Reinhoudt D.N. J. Org. Chem. 1992, 57, 1313-1316.

14. Sun H., Han J., Gao Ch. Polymer 2012, 53, 2884-2889.

15. Talanov V.S., Bartsch R.A. J. Chem. Soc., Perkin Trans. 1 1999, 14, 1957-1961.

16. Creaven B.S., Gernon T.L., McGinley J., Moore A.-M., Toftlund H. Tetrahedron 2006, 62, 9066-9071.

17. Bew S.P., Brimage R.A., L'Hermite N., Sharma S.V. Org. Lett. 2007, 9, 3713-3716.

18. Dondoni A., Marra A. J. Org. Chem. 2006, 71, 7546-7557.

19. Kawaguchi M., Ikeda A., Shinkai S. J. Chem. Soc., Perkin Trans. 1 1998, 2, 179-184.

20. Flídrová K., Tkadlecová M., Lang K., Lhoták P. Tetrahedron Lett. 2012, 53, 678-680.

21. Bernardi S., Fezzardi P., Rispoli G., Sestito S.E., Peri F., Sansone F., Casnati A. Beilstein J. Org. Chem. 2014, 10, 1672-1680.

22. Burilov V., Nugmanov R., Ibragimova R., Solovieva S., Antipin I., Konovalov A. Mendeleev Commun. 2013, 23, 113-115.

23. Verboom W., Durie A., Egberink R.J.M, Asfari Z., Reinhoud D.N. J. Org. Chem.1992, 57, 1313-1316.

24. Burilov V.A., Epifanova N.A., Popova E.V., Vasilevsky S.F., Solovieva S.E., Antipin I.S., Konovalov A.I. Russ. Chem. Bull. 2013, 62, 767-772.

25. Creary X., Anderson A., Brophy C., Crowell F., Funk Z. J. Org. Chem. 2012, 77, 8756-8761.

26. Latypov Sh., Epifanova N., Popova E., Vasilevsky S., Solovieva S., Antipin I., Konovalov A. Appl. Magn. Reson. 2011, 41, 467-475.

27. Ranganathan R., Vautier-Giongo C., Bales B.L. J. Phys. Chem. B 2003, 107, 10312-10318. 